\title{
Comparison of the postoperative first and fifth year outcomes in patients who had undergone thymectomy for Myastenia Gravis
}

\section{Myastenia Gravis için timektomi yapılan hastaların postoperatif birinci ve beşinci yıl sonuçlarının karşılaştırılması}

\author{
Koray DURAL'ª, Nesimi GÜNAL ${ }^{1}$, Bülent KOÇER ${ }^{2}$, Gültekin GÜLBAHAR ${ }^{3}$, Bilge KOÇER ${ }^{4}$ \\ 'Kırıkkale University, School of Medicine, Department of Thoracic Surgery, Kırıkkale, \\ ${ }^{2}$ Ankara Numune Education and Research Hospital, Department of Thoracic Surgery, Ankara, \\ ${ }^{3}$ Sincan Goverment Hospital, Department of Thoracic Surgery, Ankara, \\ ${ }^{4}$ Yıldırım Beyazıt Education and Research Hospital, Department of Neurology, Ankara, TURKEY
}

\begin{abstract}
Aim: The efficiency of thymectomy for treating patients with Myasthenia gravis is a controversial issue. Thus, this study aimed to investigate the efficiency of thymectomy in the treatment of myasthenia gravis based on long-term follow-up results.

Material and Methods: The first and fifth year clinical outcomes of 27 patients who had undergone median sternotomy and extended thymectomy for myasthenia gravis between January 1995 and January 2004 were compared statistically.

Results: No statistically significant differences were found between the postoperative first and fifth year clinical outcomes of the patients.

Conclusions: Thymectomy is a reliable method in the treatment of myasthenia gravis with respect to its long-term outcomes. The outcomes obtained at the end of the first and fifth year of thymectomy are not different.
\end{abstract}

Keywords: Myasthenia Gravis, thymectomy, treatment outcome

\section{ÖZET}

Amaç: Myastenia gravis hastalarının tedavisinde timektominin etkinliği tartışmalıdır. Bu çalışmada myastenia graviste uzun dönem takip sonuçlarına göre timektomi etkinliğinin araştırılması amaçlandı.

Gereç ve Yöntemler: Ocak 1995 ile Ocak 2004 arasında myastenia gravis nedeniyle sternotomi ve ekstended timektomi uygulanan 27 hastanın birinci ve beşinci yıllardaki klinik sonuçları istatistiksel olarak karşılaştııılı.

Bulgular: Hastaların postoperatif birinci ve beşinci yıllardaki klinik sonuçları arasında istatistiksel fark saptanmadı.

Sonuçlar: Uzun dönem sonuçlarının iyi olması nedeniyle timektomi myastenia gravis tedavisinde güvenilir bir yöntemdir. Timektomi sonrası birinci ve beşinci yıllar sonunda elde edilen sonuçlar arasında farklılık yoktur.

Anahtar Kelimeler: Myastenia Gravis, timektomi, tedavi sonuçları

Corresponding Author a : Koray DURAL, M.D. Kırıkkale Üniversitesi Tıp Fakültesi, Göğüs Cerrahisi Anabilim Dalı, 71450,

Kırıkkale, TURKEY

Phone:+90 4444071 / 5313, 05054454548

e-mail:koraydural@yahoo.com

Received: 24.04.2015 Accepted: 04.06.2015 


\section{Introduction}

Myasthenia gravis (MG) is a neurological disease characterized with development of abnormal antibodies against acetylcholine receptors at the neuromuscular junction. The symptoms include progressive ocular, extremity, and respiratory muscle weakness [1]. Since the definition of thymectomy by Blalock, a consensus has been reached on the efficiency of thymectomy in the treatment of MG. However, controversies on patient selection, operation time, and operation method, particularly with the introduction of minimally invasive surgery, have sustained [2]. Although some authors have claimed that in time, better outcomes would be obtained with thymectomy, few studies have compared the short and long-term outcomes of thymectomy.

\section{Material and Methods}

Thirty patients who were diagnosed with MG by an experienced neuromuscular diseases specialist based on the clinical findings, EMG and tensilon test results, and acetylcholine receptor antagonist level, were underwent thymectomy between January 1995 and January 2004. One patient who died on the postoperative day 30 due to respiratory failure and two, died due to infection at 3 and 5 months were not included in the study. The remaining 27 patients were followed-up by face-to-face interviews and neuromuscular examinations as well as telephone interviews. The results of 10 patients in the study group who were operated between January 1995 and January 2000 were published in 2000, and the results of 15 patients who were operated between January 1995 and January 2002 were published in 2003 [3].

Preoperative clinical classification of the patients was made according to Osserman classification. The patients were classified and grouped according to their conditions such as; no use of medication (has no symptoms; Group A); apparent clinical improvement (obvious improvement in symptoms, decrease in drug doses after operation; Group B); partial improvement (regression in the symptoms in comparison to the preoperative condition with no change in medications; Group C); no clinical change (symptoms and drug use are the same after the operation; Group D), and deterioration in the condition after the operation (Group E) [3].

The clinical outcomes, social activities, and the status of medication use were recorded for each patient on the study files. The clinical classification by a Task Force of the Myasthenia Gravis Foundation of America (MGFA) [4] was adapted to comprise 5 classes, and twelve patients who were operated between 2002 and 2004 were preoperatively and postoperatively classified accordingly. The postoperative 1st and 5th year status of the patients were classified according to MGFA Change in Status classification as; Improved (I),
Unchanged (U), Worse (W), Exacerbation (E), and Died (D). In addition to these evaluations, the changes in the social life activities of the patients and their degree of satisfaction with their postoperative life were recorded for the postoperative year 1 and 5 . The results of the neuromuscular examinations, social activities, and the status of drug use for the postoperative 1 st and 5th years were recorded for each patient on the study cards.

Surgery: Mediastinal fat tissue was completely removed through median sternotomy with the margins of diaphragm below and thyroid above and phrenic nerves on the sides (Extended thymectomy).

Statistical Analyses: Chi-square test was used to compare the first and fifth year clinical outcomes of the patients. $\mathrm{P}<0.05$ was considered as statistically significant.

\section{Results}

Of the 27 patients, 10 were male and 17 were female. The age range of the patients was 14-67 years (Mean age: 34.6 ).

According to MGFA clinical classification, preoperatively none of the patients was classified in class IV and V. The majority of the patients (51.8\%) were classified as Class III (Table 1 ).

Table 1. The distribution of the patients according to MGFA clinical classification.

\begin{tabular}{|l|l|l|}
\hline MGFA clinical classification & Number of patients & Rate (\%) \\
\hline Class I & 1 & 3.7 \\
\hline Class II & 12 & 44.4 \\
\hline Class III & 14 & 51.8 \\
\hline Class IV & - & - \\
\hline Class III & - & - \\
\hline
\end{tabular}

The evaluation of the specimens obtained intraoperatively revealed thymoma in 5 patients (18.5\%) and thymic hyperplasia in 13 patients $(48.1 \%$, which was the most common histopathological diagnosis) (Table 2). Comparison of the postoperative first and fifth year outcomes of the patients were shown in Table 3.

Table 2. The distribution of the patients according to histopathological diagnosis.

\begin{tabular}{|l|l|l|}
\hline Histopathological diagnosis & Number of patients & Rate (\%) \\
\hline Thymic Hyperplasia & 13 & 48.1 \\
\hline Thymolipoma & 3 & 11.1 \\
\hline Thymoma & 5 & 18.5 \\
\hline No thymic tissue was detected & 6 & 22.2 \\
\hline
\end{tabular}


Table 3. Comparison of the postoperative first and fifth year outcomes of the patients.

\begin{tabular}{|l|l|l|l|l|l|l|l|l|l|l|}
\hline & \multicolumn{2}{|c|}{$\mathrm{I}$} & \multicolumn{2}{c|}{$\mathrm{U}$} & \multicolumn{2}{c|}{ W } & \multicolumn{2}{c|}{$\mathrm{E}$} & \multicolumn{2}{c|}{$\mathrm{D}$} \\
\hline & $\mathrm{n}$ & $\%$ & $\mathrm{n}$ & $\%$ & $\mathrm{n}$ & $\%$ & $\mathrm{n}$ & $\%$ & $\mathrm{n}$ & $\%$ \\
\hline 1st year & 19 & 70 & 6 & 22.2 & 2 & 7.4 & - & - & - & - \\
\hline 5th year & 19 & 70 & 7 & 25.9 & 1 & 3.7 & - & - & - & - \\
\hline
\end{tabular}

Abbreviations: (I) improved, (U) unchanged, (W) worse, (E) exacerbation, and (D) died, (n) number of patients.

Nineteen patients (70\%) in Group I (improved) who significantly benefited from the operation according to first year outcomes remained in the same group in the postoperative fifth year. Two patients were in Group W (worse) in the postoperative first year, and the condition of one of these patients partially improved at the end of the postoperative fifth year, resulting from drug use, and the patient was classified in Group $U$ (unchanged) at the end of the postoperative fifth year.

The patients stated that they could generally carry out daily activities such as cooking, and cleaning, as well as participating in social activities such as meetings and trips and reported no differences in their standards of social activities and daily life for the first and fifth years.

Of the 19 patients in Group I, one patient, who was a 14-yearold student, was able to complete his education that was preoperatively interrupted because of MG without any problems after thymectomy. A 23-year-old female patient got married and had a baby after thymectomy. All of the 19 patients in Group I were able to carry out their preoperatively routine activities. The female patients, most of whom were housewives, stated that postoperatively, they were able to perform activities, such as cooking, cleaning, and caring for children, that they were able to do before they were diagnosed with the disease. The male patients reported that they were not able to perform tasks requiring excessive physical strength, but they were able to perform easily activities such as walking, social meetings. All of the 19 patients in Group I reported that the operation improved their quality of life and they were satisfied with their decision for an operation. The neuromuscular examination results of these patients for the first and fifth postoperative years were not different. Similarly, no significant differences were noted in the quality of their social life and satisfaction with the outcome of the operation.

None of the patients followed-up died between the postoperative first and fifth years, but considering all of the 30 patients who underwent thymectomy, one patient $(3.3 \%)$ died in the early stage, while three patients (10\%) died in the late stage.

\section{Discussion}

Various opinions have been expressed on the use of thymectomy and the factors affecting thymectomy outcomes in MG patients since the definition of thymectomy by Blalock
[2]. Despite few objections [4], a consensus on the efficiency and requirement for thymectomy prevails [5-10]. However, selection of the patients who would benefit most from thymectomy and the optimal operation method have been the focus of recent studies [8,11-13]. Several reports have shown beneficial effects of a short interval between MG diagnosis and thymectomy on the outcome of surgery. In an earlier study, we reported that an interval, shorter than one year, positively affects the outcomes [3]. It is commonly held that with thymectomy, ideal effect is obtained within the first year of MG diagnosis. The efficiency of the operation gradually diminishes after two years. Nevertheless, longer interval should not prevent interventions through thymectomy $[4,11,14,15]$. The positive effects of a short interval between the diagnosis and thymectomy have not been clearly demonstrated. Still, we believe as the interval is prolonged, the severity of the damage at the neuromuscular junction associated with MG increases and even when it is eliminated, the damage may not be completely reversible.

Literature reveals many studies reporting the factors affecting the efficiency of thymectomy in MG. Several factors such as age, sex, time interval between diagnosis and thymectomy, presence of thymoma, age at onset, clinical staging, and surgical method used have been investigated by various studies. However, there is no consensus on either one of these factors $[7,16]$. Although some studies have reported no differences in remission rates with thymectomy performed before sternotomy [12,17-19], many surgeons of today still perform extended thymectomy method through sternotomy $[5,7-9,11,13]$. The rates of complete remission as a response to thymectomy in patients who stop taking the medication and return to their routine activities range from $10 \%$ to $40 \%$, which suggests that factors that affect the outcome after thymectomy are not clearly defined [20,21].

Some studies on MG patients that had undergone thymectomy claim that ideal results will be attained in one year, while in other studies with long-term follow-up, increased remission rates have been reported. Zielinsk et al [13] determined a complete remission rate of $29.3 \%$ in the first year and $46.6 \%$ in the fourth year of thymectomy. In the same study, these rates were $10 \%$ in the first year and $21.7 \%$ in the sixth year of sternal thymectomy. In the study by Masaoka et al [16] 286 nonthymomatous MG patients were evaluated and the remission rates in the first, fifth and tenth years of thymectomy were respectively as $22.4 \% ; 45.8 \%$, and $55.7 \%$. Similarly, Park et al [9] determined a complete stable remission rate of $24.9 \%$ for the fifth year and $37.3 \%$ for the tenth year, indicating a cumulative increase in the remission rate. On the other hand, Huang et al [12] reported that the rates of complete remission increase in years but remain stable after the fourth year. Despite the reports of increased rates of remission, Roth et al [22] determined some relapses many years after the operation but found no significant differences between the short-term and 
long-term outcomes. In the same study, $90 \%$ of the patients who were followed up for 13 years, reported satisfaction with their life quality, and $65 \%$ returned to their full time jobs, and $61 \%$ reported that they were capable of doing sports such as horseback riding, walking, and swimming regularly. However, the authors determined no statistically significant differences between the remission rates.

Life standards of most MG patients usually decline, but with effective therapy, these standards can be regained. In our patient group, one of the four patients who had remissions, a 14-year-old student, was able to complete his education which was interrupted during preoperative period after thymectomy. A 23-year-old female patient got married and had a baby. The other two patients, one is retired and the other a housewife, fully returned to their past active lives. These four patients with complete remission were able to perform the same activities that they could perform before the onset of the disease. Of 14 patients with remission, most were housewives and they reported that they were able to do their housework such as cooking and cleaning and take care of children as they did before. However, they got tired in a relatively shorter time compared to their disease free state. Male patients reported that they could not carry out activities that required serious physical strength, but were able to perform activities such as walking and participating in social gatherings. All of the 18 patients with either complete or partial remission stated that the operation improved their life quality and that they were happy to have consented to the operation.

In the evaluation of the patients with long-term follow-up after the first year, no mortality occurred among 27 patients. In the comparisons of the first and fifth year drug use, in only three patients, changes in the drug dose were noted. One of these patients, a 27-year-old female, continued to take an increased dose of anticholinesterase and steroid drug in the postoperative first year, while the dose was reduced in the third year to the level of preoperative year, and thus, the patient was classified in Group D, rather than Group W. Of the other two patients from Group I, a 62-year-old woman stopped taking the drugs in the postoperative first year and returned to routine activities. In the fifth year, however, she started to take much lower doses of steroids than preoperative doses. The other patient, a 44-year-old woman significantly reduced the dose of the drug in the first year compared to the preoperative dose and stopped taking the drug in the third year, and was able to carry out her daily activities in the fifth year without using any drugs.

The patients reported no difference in the life quality for the first and fifth year of the operation. Nevertheless, drug doses were increased at regular intervals for short periods in all of the 15 patients who were taking drugs. One patient with complete remission who got pregnant while she was not taking the drug reported that she used drugs at certain intervals but stopped using with the termination of pregnancy. The reasons to increase drug doses were reported by the patients, as seasonal changes and upper respiratory tract infections in winter months. Strikingly, despite a stability achieved in the general condition, there were times of aggravation. This suggests that the factors causing the disease are not completely eliminated with thymectomy, but the number of causative factors were reduced or their effects were suppressed. Failure to obtain optimal outcomes after thymectomy procedure have been attributed to several factors, such as incomplete thymectomy, irreversible neuromuscular joint damage, presence of the peripheral lymphoid nodules and spleen that can have thymic effects, presence of peripheral T cells with long life, and heterogeneous disease mechanism (different thymic effects on patients) [22].

In some studies, better long-term postoperative outcomes have been reported $[9,13,15]$. However, these studies have not provided a clear explanation for this hypothesis. In advanced ages, myasthenia findings may be triggered by physiological muscular weakening; however, this was not supported by any findings in our study.

In our series, no results have been obtained supporting that the pace of recovery will improve with prolonged time after the first year of thymectomy. In addition, no statistically significant differences were found between the first and fifth year drug use and general conditions of the patients.

As a conclusion thymectomy is a safe and reliable method of treatment for Myasthenia Gravis. Nevertheless, no statistically significant differences were determined between the first and fifth year clinical outcomes.

\section{Declaration of conflicting interests}

The authors declared no conflicts of interest with respect to the authorship and/or publication of this article.

\section{Funding}

The authors received no financial support for the research and/or authorship of this article.

\section{References}

1. Hohlfeld R, Wekerle $\mathrm{H}$. The thymus in myasthenia gravis. Neurol Clin 1994; 12: 331-342.

2. Blalock A, Harvey AM, Ford FR, Lilienthal J Jr. The treatment of myasthenia gravis by removal of the thymus gland. JAMA 1941; 117: 1529-33.

3. Dural K, Yıldırım E, Han S, Ozısık K. The importance of the time interval between diagnosis and operation in myasthenia gravis patients. J Cardiovasc Surg 2003; 44; 125-9.

4. Jaretzki A, Barohn RJ, Ernstoff RM et al. Myasthenia gravis: recommendations for clinical research standarts. Ann Thorac Surg 2000; 70: 327-34. 
5. Werneck LC, Cunha FMB, Scola RH. Myasthenia gravis: a retrospective study comparing thymectomy to conservative treatment. Acta Neurol Scand. 2000; 101: 41-6.

6. Hase R, Sugiura H, Fukunaga A, Takahashi H. Clinical outcomes following extended thymectomy for myasthenia gravis: report of 17 cases. Ann Thorac Cardiovasc Surg. 2006; 12: 203-6.

7. Yuan HK, Huang BS, Kung SY, Kao KP. The effectiveness of thymectomy on seronegative generalized myasthenia gravis: comparing with seropositive cases. Acta Neurol Scand 2007; 115: 181-4.

8. Ozdemir N, Kara M, Dikmen E, Nadir A. Predictors of clinical outcome following extended thymectomy in myasthenia gravis. Eur J Cardiothorac Surg 2003; 23: 233-7.

9. Shrager JB, Nathan D, Brinster CJ, Yousuf O. Outcomes after 151 extended transservical thymectomies for myasthenia gravis. Ann Thorac Surg 2006; 82: 1863-9.

10. Park IK, Choi SS, Lee JG, Kim DJ, Chung KY. Complete stable remission after extended transsternal thymectomy in myasthenia gravis. Eur J Cardiothorac Surg 2006; 30: 525-8.

11. Kawaguchi N, Kuwabara S, Nemoto Y, Fukutake T. Effects of thymectomy on late-onset myasthenia gravis without thymoma. Clin Neurol Neurosurg 2007; 109: 858-61.

12. Huang $\mathrm{CS}$, Hsu HS, Huang BS, Lee HC. Factors influencing the outcome of transsternal thymectomy for myasthenia gravis. Acta Neurol Scand 2005; 112: 108-14.

13. Zielinski M, Kuzdzal J, Szlubowski A. Transservical-SubxiphoidVideothorascopic "Maximal" thymectomy-operative technique and early results. Ann Thorac Surg 2004; 78: 404-10.

14. Zielinski M, Kuzdzal J, Szlubowski A, Soja J. Comparison of late results of basic transsternal and extended transsternal tymectomies in the treatment of myasthenia gravis. Ann Thorac Surgery 2004; 78: 253-8.
15. Kattach H, Anastasiadis K, Cleuziou J, Buckley C, Shine B. Transsternal thymectomy for myasthenia gravis; surgical outcome. Ann Thorac Surg 2006; 81: 305-8.

16. Masoaka A, Yamakawa Y, Niwa H, Fukai I. Extended thymectomy for myasthenia gravis patients; a 20-year review. Ann Thorac Surg. 1996; 62: 853-9.

17. Kim HK, Park MS, Choi YS, Kim K. Neurologic outcomes of thymectomy in myasthenia gravis: comperative analysis of the effect of thymoma. J Thorac Cardiovasc Surg. 2007; 134: 601-7.

18. Pompeo E, Nofroni I, lavicoli N. Thorascopic completion thymectomy in refractory non-thymomatous myasthenia. Ann. Thorac Surg 2000; 70: 918-23.

19. Shrager J, Deeb M, Mick R, et al. Transcervical thymectomy for myasthenia gravis achieves results comparable to thymectomy by sternotomy. Ann Thorac Surg 2002; 74: 320-7.

20. Marulli G, Rea F. Myasthenia gravis and thymectomy: many doubts and few certainties. Eur J Cardiothorac Surg. 2014. doi: 10.1093/ejcts/ezu398.

21. Yu S, Li F, Chen B, et al. Eight-year follow-up of patients with myasthenia gravis after thymectomy. Acta Neurol Scand. 2015; 131:94-101.

22. Roth $T$, Ackermann $R$, Stein $R$, Inderbitzi R. Thirteen years follow-up after radical transsternal thymectomy for myasthenia gravis. Do short-term results predict long-term outcome? Eur J Cardiothorac Surg. 2002; 21: 664-70. 